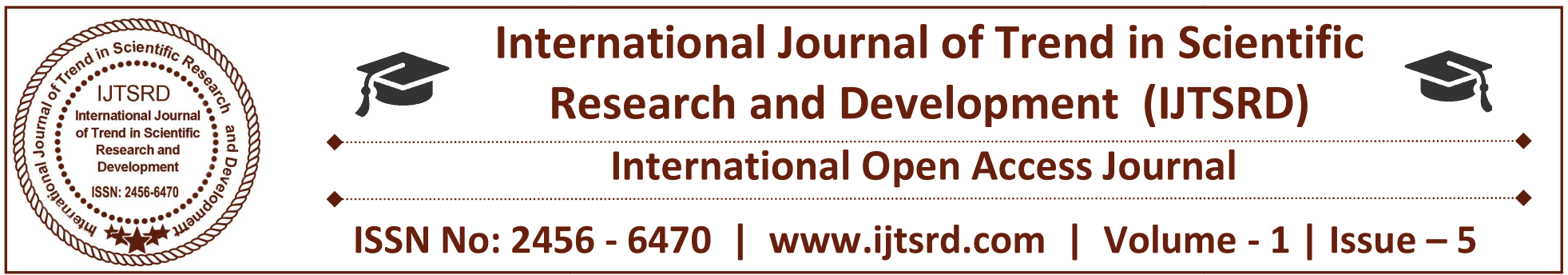

\title{
Physio-Chemical and Microbial Screening of Selected Potable Water Sold in the Nnamdi Azikiwe University, Nnewi Campus
}

\author{
P.N. Ogueche \\ Department of Human Biochemistry, Faculty of Basic \\ Medical Sciences, College of Health Sciences, \\ Nnamdi Azikiwe University P.M.B 5001, Nnewi \\ Campus, Anambra State, Nigeria
}

\section{P.A. Ejiribe}

Department of Environmental Health Sciences, Faculty of Health Sciences \& Technology, College of Health Sciences, Nnamdi Azikiwe University, Nnewi Campus, Anambra State, Nigeria

\section{C.O. Obiezue}

Department of Environmental Health Sciences, Faculty of Health Sciences \& Technology, College of Health Sciences, Nnamdi Azikiwe University, Nnewi Campus, Anambra State, Nigeria

\section{N.C. Nwankwo}

Department of Environmental Health Sciences, Faculty of Health Sciences \& Technology, College of Health Sciences, Nnamdi Azikiwe University, Nnewi Campus, Anambra State, Nigeria

\author{
I.C. Maduka \\ Department of Human Biochemistry, Faculty of Basic \\ Medical Sciences, College of Health Sciences, \\ Nnamdi Azikiwe University P.M.B 5001, Nnewi \\ Campus, Anambra State, Nigeria

\section{R.U. Udeh} \\ Department of Environmental Health Sciences,
} Faculty of Health Sciences \& Technology, College of Health Sciences, Nnamdi Azikiwe University, Nnewi Campus, Anambra State, Nigeria

\begin{abstract}
A.G. Obalim
Department of Environmental Health Sciences, Faculty of Health Sciences \& Technology, College of Health Sciences, Nnamdi Azikiwe University, Nnewi Campus, Anambra State, Nigeria

\section{J.O. Uzoigwe}

Department of Environmental Health Sciences, Faculty of Health Sciences \& Technology, College of Health Sciences, Nnamdi Azikiwe University, Nnewi Campus, Anambra State, Nigeria
\end{abstract}

\section{ABSTRACT}

Adequate supply of potable table water is a basic necessity for all mankind. Unfortunately, this basic necessity of man has been grossly deprived especially in the developing countries. Water meant for consumption must be potable: free from contamination by microorganisms and possess stable physicochemical parameters. And this is the essence of this research study. In this study, physico-chemical parameters such as colour, $\mathrm{pH}$, odour, temperature and microbial indices: Escherichia coli, Klebsiella pneumonia, Salmonella typhmurium and Streptococcus aureus were investigated in potable

packaged water sold in Nnamdi Azikiwe University, Nnewi Campus, Anambra State,Nigeria. Six different bottled and sachet water samples obtained from different manufacturers labeled B1,B2,B3,B4,B5,B6 and $\mathrm{S} 1, \mathrm{~S} 2, \mathrm{~S} 3, \mathrm{~S} 4, \mathrm{~S} 5, \mathrm{~S} 6$, respectively were examined physically, chemically and microbiologically. Physical examination of the samples showed that they were colourless and odourless. Chemical examination of the samples showed they were within the WHO standards for temperature and $\mathrm{pH}$ except for water samples S1, B4 and B5 whose $\mathrm{pH}(8.6 ; 6.2$ \& 6.0) deviated from the standard. Water samples S4, B3, B4 
and B5 indicated presence of E. coli where as S6 indicated presence of Klebsiella pneumoiae. Streptococcus aureus was present in B3. From our study, its suggestive that the packaged water analyzed were not chemically and microbiological fit for consumption though this need to be further investigated.

Key words: Potable water, Escherichia coli, Klebsiella pneumonia and Salmonella typhmurium and Streptococcus aureus.

\section{INTRODUCTION}

Adequate supply of potable table water is a basic necessity for all mankind. Unfortunately, this basic necessity of man has been compromised and neglected over the decades by successive government administrations at the expense of quality life. In many developing countries, availability of potable water has become a critical and urgent problem hence a matter of concern to families and communities (Adekunle et al., 2004). Water is an essential part of human nutrition and is required for maintenance of personal hygiene, food production and prevention of diseases (Thliza et al., 2015). It is the most abundant substance in nature and occupies about $70 \%$ of the earth's crust (Anyamene and Ojiagu, 2014; Thliza et al., 2015). Water is a biological medium which exists as solid, liquid and gas (Thliza et al., 2015). Colourless,odourless and tasteless water is vital for all known live forms. It's the major constituent of the fluid of organisms. In a recent estimate based on WHO reports suggests that $80 \%$ of all human illnesses in the developing world are caused by biological contamination (WHO, 2008). The majority of the population in developing countries is not adequately supplied with potable water, and thus obliged to use unsafe water for domestic purposes. (Ajayi, et al., 2008). Water should be clear, without disagreeable taste, color or odour for it to be deemed fit for human and animal consumption. If otherwise, then it needs to be treated, cleaned or filtered to meet established drinking standards (Aroh et al., 2013; Isikwue and Chikezie, 2014). Water can be sourced from surface such as river, streams or ground such as spring, well and borehole (Aroh et al., 2013). Agencies that regulate water quality worldwide is the World Health Organization (WHO). They determine standards and guidelines for water quality (WHO, 2001 and 2002). So as to ensure the highest quality of potable water in order to safe guard public health (Anunobi et al., 2006; Isikwue and Chikezie, 2014).
There are various water treatment processes, the major procedures are aeration, coagulation, flocculation, sedimentation, slow sand filtration, rapid filtration and disinfection (Ibemesim, 2014).

To minimize the risk of bacterial growth in drinking water, (WHO, 2004) reported that chlorination, ozoniation, ultra violet radiation and advanced oxidation processes are widely accepted for disinfection of drinking water.

Unsafe water is a global public health threat, placing persons at risk for a host of diarrhea and other diseases as well as chemical intoxication (Ashaye, 2001). The exposure to this microbial contaminant can lead to microbial infections like cholera, typhoid fever and dysentery. Varieties of microorganisms are water borne and due to this fact, conformation with microbiological standard is of special interest because of the capacity of water to spread diseases within a large population (Omezuruike et al., 2008). Whenever water is submitted for testing, it will also be analyzed for the bacteriological property. Microbial character of bottled and sachet potable water can be influenced by certain factors like handling, treatment and expiry. Packaged water is one of the main sources of water supply in most Nigerian institutions and since it is used for human consumption, it should meet required microbial standards. Hence, microbial analysis of packaged water sold at tertiary institutions must be carried out to monitor the effectiveness of treatment process. And this is the essence of this research. To determine presence of pathogenic microorganisms such as E. coli, Klebsiella pneumoniae, Salmonella typhmurium and Streptococcus aureus in potable table water (sachet and bottled) sold in the Nnamdi Azikiwe University, Nnewi Campus, Anambra State, Nigeria.

\section{MATERIALS AND METHOD}

The materials used in this research work were sachet and bottled water, bought from vendors located within the Nnewi Campus, of Nnamdi Azikiwe University, Anambra State, Nigeria. The water samples were produced from six different manufacturers labeled S1 - S6 and B1 - B6. The letters $\mathrm{S}$ and $\mathrm{B}$ indicate sachet and bottled water respectively. The names of these manufactures of the table water were withheld and labeled with letters in accordance with best practices. 
The physical properties of the table water used in this study were visually determined, however the chemical property $(\mathrm{pH})$ were determined using $\mathrm{pH}$ meter. The $\mathrm{pH}$ meter was standardized using phosphate buffer of $\mathrm{pH}$ 7.0. Microbial screenings were carried out using standard microbiological methods by the method of US Environmental Protection Agencies 2002 and Hanaor and Sorrelli 2004.

\section{BACTERIOLOGICAL WATER ANALYSIS}

The water sample was first mixed properly, about $50 \mu 1$ of water sample was aseptically collected directly from each of the water containers using a sterile wire loop, it was cultured on two neutral agar media. One set of the agar was incubated at room temperature, $25^{\circ} \mathrm{C}$ and the other at $37^{\circ} \mathrm{C}$ for 48 hours in an incubator. At the end of this incubation, the agar media were visually examined for bacterial growth, count and cultural characteristics. Bacterial colony forming units (CFU) of 30 and above were considered significant growth. Grams stain and cultural characteristics on the selective medium were used to identify the cultured bacterial organisms.

\section{RESULTS AND DISCUSSION}

From table 1.0, the sachet water samples were colourless and odourless, and were within the WHO standard. It was observed that the water temperature fell within the WHO acceptable level. Chemical examinations $(\mathrm{pH})$ of the sachet water samples: $\mathrm{S} 2$, S3, S4, S5 and S6 were within the WHO acceptable range while the $\mathrm{pH}$ of water samples $\mathrm{S} 1$ fell outside the WHO acceptable range. In table 2.0, the bottled water samples were colourless and odourless, and were within the WHO standard. It was observed that the water temperature of the six different bottled water samples had a constant value of $29^{\circ} \mathrm{C}$ and that was within the range of WHO acceptable level. The $\mathrm{pH}$ of bottled water samples: B1, B2, B3, and B6 had the WHO acceptable range whereas the B4 and B5 had values slightly acidic, which were outside the WHO limit. In table 3.0, sachet water samples: S4 and S6 indicated presence of Klebsiella pneumoiae and E. coli respectively while $\mathrm{S} 1, \mathrm{~S} 2, \mathrm{~S} 3$ and S5 showed absence of microorganism under study. In water samples B3,B4 and B5 indicated presence of E. coli while B1,B2, and B6 indicated absence of microorganism under study. In addition, streptococcus aureus is present in B3 and its not seen in any other bottled water samples.

\section{Discussion:}

In human cultural evolution, the importance of water cannot be overemphasized, such that settlement was preferred along areas where there were water sources (streams and rivers). This is to depict that adequate supply of potable table water is a basic necessity for all mankind. Unfortunately, this basic necessity of man has been compromised and neglected over the decades by successive government administrations at the expense of quality life. In many developing countries of the world, drastic potable water scarcity has become critical and compulsory threat to all life forms especially the human beings. It has been reported that drinking of unhygienic water in poor countries has resulted in the death of 2.2 million people per annum, 99 percent of these are children under the age five (WHO, 2004). This threat of water scarcity demand declaration of state of emergency to any sensible government. Water meant for consumption must be potable: free from contamination by microorganisms and possess stable physiochemical parameters.

In tables 1.0 and 2.0, the water samples under study had temperatures with the acceptable WHO range. This indicates that the potable water samples had stable room temperatures. Similarly, the colour and odour of the water samples showed that all water samples were colourless and odourless respectively, thus within the WHO requirement (not objectionable) . The water samples under study can be described as being attractive and may account for its patronage by the inhabitants of the study area. Our observation is in line with works done by Anyaeze et al.,2013 and Maduka et al., 2014. World Health Organization recommended that potable water for consumption should not contain any microorganism known to be pathogenic (WHO, 1984). From our results, the sachet water samples (S4 and S6) indicated presence of Klebsiella pneumoniae and E. coli respectively where as the bottled water samples (B3, B4 and B5) indicated presence of $\mathrm{E}$. coli. The presence of $\mathrm{E}$ coli in a water sample according to reports of Adekunle et al., 2004, and Edema et al., 2001 is an indication of water pollution. This is because the presence of $\mathrm{E}$. coli is most often accompanied by the presence of dangerous enteric pathogens like Shigella, Salmonella and Campylobacter species (Shilklomanov, 2000 and Edberg et al., 2000). However, streptococcus aureus was present in one of the bottled water samples labeled B3. The microorganism under study such as Salmonella typhmurium was absent in all the water 
(sachet and bottled) samples analyzed. The absence of S.typhmurium in all the water samples suggests that the water samples under study is free such organism and its attendant disease causing effects specifically typhoid fever. In two separate studies of Maduka et al.,2014 and Tortora et al., 2002 absence of S.typhmurium in a water samples suggests that typhoid fever may not be contacted from the water samples. The bacteriological quality of drinking water is of immense importance because several studies have attributed several disease outbreaks to untreated or poorly treated water containing bacteria pathogens that have been isolated from sachet water (Shear et al., 1995).

\section{CONCLUSION}

The presence of microorganisms: E. coli, Klebsiella pneumoniae, and Streptococcus aureus as well deviation in the physio-chemical properties of potable packaged table water (sachet and bottled) sold in one of the Nigerian Tertiary Institutions have been established in this study. The contamination could be as a result of unhygienic acquisition of water source, poor handling, processing and after production effects especially expiration. Water with high acidity or alkalinity as well the bacteria enumerated above (E. coli, Klebsiella pneumoniae, and Streptococcus aureus) is not safe or potable for human consumption, hence, water vended for public consumption need to be re-examined. And relevant agencies saddled with the responsibility of regulating standards in quality water production such as the National Agency for Food \& Drug Administration Control (NAFDAC) and World Health Organisation (WHO) should be alive and dutiful.

Table 1.0 Physicochemical Properties of the Potable Satchet Water

\begin{tabular}{|l|l|l|l|l|l|l|l|}
\hline $\begin{array}{l}\text { Physical/ } \\
\text { chemical } \\
\text { parameters }\end{array}$ & \multicolumn{1}{|c|}{ S1 } & \multicolumn{1}{|c|}{ S2 } & \multicolumn{1}{|c|}{ S4 } & \multicolumn{1}{|c|}{ S5 } & \multicolumn{1}{|c|}{ S6 } & \multicolumn{1}{|l|}{$\begin{array}{c}\text { WHO } \\
\text { ACEPTABLE } \\
\text { RANGE }\end{array}$} \\
\hline Colour & Colourless & Colourless & Colourless & Colourless & Colourless & Colourless & Colourless \\
\hline pH & 8.6 & 8.1 & 7.9 & 7.6 & 7.7 & 7.8 & $6.5-8.5$ \\
\hline Temperature & 29 & 30 & 30 & 29 & 29 & 28 & $20-30$ \\
\hline Odour & Odourless & Odourless & Odourless & Odourless & Odourless & Odourless & Unobjectionable \\
\hline
\end{tabular}

Table 2.0 Physicochemical Properties of the Potable Bottled Water

\begin{tabular}{|l|l|l|l|l|l|l|l|}
\hline $\begin{array}{l}\text { Physical/chemica } \\
\text { I parameters }\end{array}$ & \multicolumn{1}{|c|}{ B1 } & \multicolumn{1}{|c|}{ B2 } & \multicolumn{1}{|c|}{ B3 } & \multicolumn{1}{|c|}{ B5 } & \multicolumn{1}{|c|}{$\begin{array}{c}\text { B6 } \\
\text { ACCEPTA BLE } \\
\text { RANGE }\end{array}$} \\
\hline Colour & Colourless & Colourless & Colourless & Colourless & Colourless & Colourless & Colourless \\
\hline pH & 7.4 & 7.0 & 7.1 & 6.2 & 6.0 & 6.8 & $6.5-8.5$ \\
\hline $\begin{array}{l}\text { Temperature } \\
\left({ }^{\circ} \mathrm{C}\right)\end{array}$ & 29 & 29 & 29 & 29 & 29 & 29 & $20-30$ \\
\hline Odour & Odourless & Odourless & Odourless & Odourless & Odourless & Odourless & Unobjectionable \\
\hline
\end{tabular}


Table 3.0 Microbial Screening of the Potable SATCHET Water

\begin{tabular}{|l|l|l|l|l|l|l|}
\hline \multicolumn{1}{|c|}{ Microorganisms } & \multicolumn{1}{c|}{ S1 } & \multicolumn{1}{c|}{ S2 } & \multicolumn{1}{c|}{ S3 } & \multicolumn{1}{c|}{ S4 } & \multicolumn{1}{c|}{ S5 } & S6 \\
\hline Escherichia coli & - & - & - & + & - & + \\
\hline Klebsiella pneumonia & - & - & - & - & - & - \\
\hline Salmonella typhmurium & - & - & - & - & - & - \\
\hline Staphylococcus aureus & - & - & - & - & - & - \\
\hline Streptococcus faecalis & - & - & - & - & - & - \\
\hline
\end{tabular}

+ means presence of microbial contamination by one of the organisms under study.

- means absence of microbial contamination by one of the organisms under study

Table 4.0 Microbial Screening of the Potable Bottled Water

\begin{tabular}{|l|l|l|l|l|l|l|}
\hline Microorganisms & \multicolumn{1}{|c|}{ B1 } & \multicolumn{2}{c|}{ B2 } & \multicolumn{2}{c|}{ B3 } & \multicolumn{2}{c|}{ B4 } & \multicolumn{2}{c|}{ B5 } & B6 \\
\hline Escherichia Coli & - & - & + & + & + & - \\
\hline Klebsiella Pneumoniae & - & - & - & - & - & - \\
\hline $\begin{array}{l}\text { Salmonella } \\
\text { Typhmurium }\end{array}$ & - & - & - & - & - & - \\
\hline Staphylococcus Aureus & - & - & - & - & - & - \\
\hline Streptococcus Faecalis & - & - & + & - & - & - \\
\hline
\end{tabular}

+ means presence of microbial contamination by one of the organisms under study.

- means absence of microbial contamination by one of the organisms under study

\section{REFERENCES}

1) Adegoke, O.O., Bamigbowu, E.O., Oni, E.S. and Ugbaja, K.N. (2012). Microbiological examination of sachet water sold in Nnewi, Anambra State, Nigeria. Global Research Journal of Microbiology 2: 62-66.

2) Adekunle, L.V., Sridhar,M.K.C., Ajayi, A.A., Oluwude, P.A. and Olawuyi J.F.(2004). An assessment of the health and social economic implications of sachet water in Ibadan,Nigeria: A public health challenge. African Jounal Biomedical Research. 7:5-8.

3) Adetunde, L.A., Sackey, I., Elvis, B.B. and Afarawoye, A.E. (2014). Bacteriological quality of sachet water produced and sold in the Bolgatanga Municipal in the Upper East Region of Ghana. International Journal of Modern Social Sciences 3: 36-43.

4) Ajewole, I.A. (2005). Water an Overview, Food Forum, A Publication of the Nigerian Institute of Food Science and Technology, September 2005, 4(1):15.

5) Akinde, S.B., Nwachukwu, M.I. and Ogamba, A.S. (2011). Storage effects on the quality of sachet water produced within Port Harcourt metropolis, Nigeria. Journal of Biological Sciences 4: 157-164.

6) Anuobi, C.C., Onajole, A.T. and Ogunnowo, B.E. (2006). Assessment of the quality of packaged water on sale in Onitsha metropolis. Nigerian Quarterly Journal of Hospital Medicine 16: 5659.

7) Anyamene, N.C. and Ojiagu, D.K. (2014). Bacteriological Analysis of sachet water sold in Akwa Metropolis, Nigeria. International Journal of Agriculture and Biosciences 3: 120-122.

8) Aroh, K.N., Eze, E.M., Ukaji, D., Wachuku, C.K., Gobo, A.E., Abbe, S.D., Teme, S.C. and Igoni, A.H. (2013). Health and environmental components of sachet water consumption and trade in Aba and Port Harcourt, Nigeria. Journal of Chemical Engineering and Material Science 4: 13-22.

9) Backer and Howard, (2002). Water disinfection for International and wilderness travelers. clinical infectious disinfection. 34(3):335-364.

10) Banu, N. and Menakuru, H. (2010). Enumeration of microbial contaminants in sachet water: A public health challenge. Health 6: 582-588. 
11) CDC, (2007). Guidelines for isolation precautions: preventing transmission of infectious Agent in Healthcare settings.

12) Danso-Boateng, E. and Frimpong, I.K. (2013). Quality analysis of plastic sachet and bottled water brands produced or sold in Kumasi, Ghana. International Journal of Development and Sustainability 4: 2222-2232.

13) Diersing, N. (2009). Water quality: Frenquently asked questions. PDA NOAA. Available at http:// floridakeyr.noaa.gov / pdf / wqfaq.pdf. Accessed; 13th July, 2015.

14) Edberg, S.C., Rice, E.W., Kar, R.J. and Allen, M.J. (2000). Escherichia coli. The best biological water indicator for public health protection. J. App. Microbial. 88:1068-1168.

15) Edema, M.O., Omemu, A.M. and Fapetu, O.M. (2001). Microbiology and Physico- Chemical Analysis of Different Sources of Drinking Water in Abeokuta, Nigeria. Niger, J. Microbiology.; 15(1):57-61.

16) Hanaor, D.A.H. and Sorrelli (.C. 2004). Sand supported mixed-phase. $\mathrm{T}_{1} \mathrm{O}_{2}$ photocatalyst for water determination applications. Advanced Engineering materials; 16(2):248 - 257.

17) Hughes, J.M. and Koplan, J.P. (2005). Saving lives through global safe water. Journal of Infectious Diseases 11: 1636- 1637.

18) Ibemesim, A.O. (2014). Comparative study of qualities of sachet and bottle water sold on the streets of Abuja, Nigeria. South American Journal of Public Health 2: 308-328.

19) Isikwue, M.O. and Chikezie, A. (2014). Quality assessment of various sachet water brands marketed in Bauchi metropolis of Nigeria. International Journal of Advances in Engineering and Technology 6: 2489-2495.

20) Johnson, D.L., Ambrose, S.H., Bassett, T.J., Bowen, M.L., Crummey, D.E., Isaacson, J.S., Johnson, D.N., Lamb, P., Saul, M. and WinterNelson, A.E. (1997). Meaning of environmental terms. Journal of Environmental Quality 20: 581-589.

21) Kleiner, S.M. (1999). Water: An Essential but Overlooked Nutrient. J. Am. Diet. Association.; 99:200 - 206.

22) Maduka, H.C.C., Chukwu, N.C., Ugwu, C.E., Dike, C.C., Okpogba, A.N., Ogueche, P.N. and Maduka, A.A. (2014). Assessment of commercial bottled table and sachet water commonly consumed in Federal University of Technology, Owerri (FUTO), Imo State,
Nigeria using Microbiological indices. Journal of Dental and Medical Sciences 13: 86-89.

23) Nwosu, J.N. and Ogueke, C.C. (2004). Evaluation of sachet water samples in Owerri metropolis. Nigeria Food Journal 22: 164-170.

24) Okonkwo, I.O., Adejoye, O.D., Ogunusi, T.A., Fajobi, E.A. and Shittu, O.B.(2008). Microbiological and physiochemical analysis of different water samples used for domestic purposes in Abeokuta and Ojota, Lagos State, Nigeria. African Jounal Biotechnology. 7(3): 617-621.

25) Oladipo, I.C., Onyenike, I.C. and Adebiyi A.O.(2009). Microbiological analysis of some vended sachet water in Ogbomoso, Nigeria. African Journal of Food Science. 3(12):406412.

26) Omalu, I.C.J., Eze, G.C., Olayemi, I.K., Gbesi, S., Adeniran, L.A., Ayanwale, A.V., Mohammed, A.Z.and Chukwuemeka, V. (2010). Contamination of Sachet Water in Nigeria: Assessment and Health Impact. Online Journal Health and Allied Science. 9(4):15

27) Onemani, J.I. and Otun, J.A. (2003). 28th WEDC International Conference. Problems on water quality standards and monitoring in Nigeria.139-141. 200 African Journal of Food Science Technology.

28) Opara, A.U. and Nnodim, J. (2014). Prevalence of Bacteria in bottled and sachet water sold in Owerri metropolis. International Journal of Science Innovations and Discoveries 4: 117122.

29) Oyedeji, O., Olutiola, P.O. and Moninuola, M.A. (2010). Microbiological quality of packaged drinking water brands marketed in Ibadan metropolis and Ile-Ife city in South Western Nigeria. African Journal of Microbiology Research 4: 096- 102.

30) Riggs, P.J., Chelius, M.K., Iniguez, A.L., Kaeppler, S.M. and Triplett, E.W.(2001). "Enhanced maize Productivity by inoculation with diaotrophic bacteria". Australlian Journal of Plant Physiology. 29(8): 829-836.

31) Ryan , K.J. and Ray, C.C. (2004). Sheriss medical microbiology ( $4^{\text {th }}$ edition). 16(2): 529533.

32) Savage, N. and Mamadou, S. (2005). Nanomaterials and water purification. Opportunities and challenges. 7 (4-5): 331-342.

33) Shear,P., Hussein, M.A., Chowdhury, A.H. and Mamun, K.Z.(1995). Water Resources and 
Environmental transmission of multiple resistant enteric bacteria in rural Bangladesh. 89:297-303.

34) Shilklomanov,I.A. (2000). Appraisal and assessment of world water resources. Water intl. 25(1) 11-32.

35) Thliza, L.A., Khan, A.U., Dangora, D.B. and Yahaya, A. (2015). Study of some bacterial load of some brands of sachet water sold in Ahmadu Bello University (Main Campus), Zaria, Nigeria. International Journal of current Science 14:91-97.

36) Tortora, J.G., Funke R.B. and Case, L.C. (2002). Microbiology an Introduction. Media update 7 th edn. Including bibliography and index publisher.Daryl Fox. pp.258 - 260.

37) U.S Environmental Protection Agency (EPA) (2002). Method of fecal coliforms assay in Biosolids by multiple-tube fermentation procedures. Draft document No EPA- 821-R-02 - 026.

38) World Health Organisation (WHO) (1993). Guidelines for drinking water quality 2nd edition health criteria and other supporting information. WHO Geneva. 2:940-949.

39) World Health Organization (2001). Guidelines for drinking water quality: Microbiological methods, 2nd edition, Vol. 1, World Health Organization, Geneva, WHO publication, Geneva, Switzerland.

40) World Health Organization (2002). Guidelines for drinking water quality: Addendum; Microbiological agents in drinking water, 2nd edition, World Health Organization, Geneva, WHO publication, Geneva, Switzerland.

41) WHO,2004. Guidelines II for drinking water quality, vol 1. EFP/82.39. WHO,(2) Geneva 27,Switzerland.

42) WHO, (1984). Guideline for water quality. Vol. 1, H.M.S.O. Publication London. Pp 6-9. 